\title{
Comparative Histological Study on The Effect of Bone Marrow Derived Mesenchymal Stem Cells Versus Wheat Germ Oil on Acute Pancreatitis in A Rat Model
}

\section{Original Article}

\author{
Sahar Ezzat Nasr, Dina Mohamed Radwan, Alshaymaa Gamal Aboulkhair and \\ Mai Mostafa Hamed
}

Department of Histology, Faculty of Medicine, Cairo University

\begin{abstract}
Background: Acute pancreatitis (AP) is a common inflammatory disorder of digestive system. Mesenchymal stem cells (MSCs) and Wheat germ oil (WGO) could improve AP through their anti-inflammatory and antioxidant effects. Objective: Evaluate and compare the possible therapeutic effects of Bone marrow derived Mesenchymal Stem Cells (BMSCs) versus WGO on AP.

Materials and Methods: 47 adult male albino rats were divided into 4 groups. Control group I (no.=12). AP was induced in the remaining 35 rats by a single intra peritoneal (I.P) injection of L-arginine $(250 \mathrm{mg} / 100 \mathrm{~g}) .5$ rats died within the 1 st hour after AP induction, the rest were divided randomly into group II (AP group; no.=10) that received no treatment, group III (BMSCs group; no.=10) and group IV (WGO group; no.=10). One hour after AP induction, group III was injected I.P. by $1 \mathrm{ml}$ of PKH26 labeled BMSCs (1x106 cells/ml) and group IV received WGO in a dose of $3 \mathrm{ml} / \mathrm{kg}$ body weight by oral gavage every $24 \mathrm{~h}$ for 3 successive days. Blood samples were collected 24 hours and on the $4^{\text {th }}$ day after AP induction for biochemical assessment of serum amylase, lipase, interleukin-1 $\beta$ and interleukin-10. Then, animals were sacrificed and specimens from the pancreas were prepared for Hematoxylin and eosin (HandE) stain and immune-histochemical staining using inducible Nitric Oxide Synthase (iNOS) and insulin antibodies. Morphometric measurements using image analyzer were done.

Results: Group II showed extensive pancreatic damage associated with increase in serum amylase, lipase and interleukin-1B levels and reduction in interleukin-10 level. A significant increase in the area \% of iNOS immunostaining and non-significant change in insulin immunostaining were detected. On the other hand, BMSCs group and WGO group showed improvement in the biochemical, histological and immunohistochemical results with better results in BMSCs group.

Conclusion: BMSCs possess better therapeutic efficacy in treating AP compared with WGO.
\end{abstract}

Received: 14 February 2018, Accepted: 18 February 2019

Key Words: Acute pancreatitis; BMSCs; iNOS, wheat germ oil.

Corresponding Author: Alshaymaa Gamal Aboulkhair, MD, Department of Histology, Faculty of Medicine, Cairo University, Egypt, Tel.: +2 02 26433754, E-mail: gamalshaimaa@rocketmail.com

ISSN: $1110-0559$, Vol. 42 , No. 3

\section{INTRODUCTION}

Acute pancreatitis (AP) is a common inflamma $\neg$ tory disease. Most of cases show self-limited system $\neg$ ic inflammation of mild acute pancreatitis (MAP). However, $10-15 \%$ of cases show severe acute pancreatitis (SAP) with infec-tion, pancreatic necrosis, multiple organ failure and mortality rate $30-47 \% 0^{[1 \& 2]}$.

There is mainly supportive but not specific treatment for acute pancreatitis despite its increasing incidence ${ }^{[3]}$. For example, drainage, debridement and antibiotics for treatment of infected pancreatic necrosis ${ }^{[4]}$.

The early activation of intracellular pancreatic enzymes has been the basic mechanism of AP. However, other mechanisms such as oxidative stress, impaired autophagy have been involved ${ }^{[5]}$.

Mesenchymal stem cells (MSCs) could manage AP.
They differentiate in vitro into different tissues under suitable conditions ${ }^{[6]}$. They home to inflammatory tissues, secret anti-inflammatory cytokines that modulate the immune response in addition; they have antioxidant $\operatorname{effect}^{[7 \& 8]}$

Wheat germ oil (WGO) is a good antioxidant due to its high content of tocopherols (particularly vitamin E) and carotenoid. Moreover, it has anti-inflammatory effect because of its ceramide content and it contains antimicrobial compounds ${ }^{[9]}$.

This study aimed to evaluate and compare the possible therapeutic effects of Bone marrow derived Mesenchymal Stem Cells versus wheat germ oil on acute pancreatitis induced by L-Arginine in a rat model using biochemical, histological, immunohistochemical and morphometrical methods. 


\section{MATERIALS AND METHODS}

\section{Animals}

Forty-seven adult male albino rats (180- 200 gm) were housed and treated in Animal House, Faculty of Medicine, Cairo University according to the guidelines approved by the Animal Use Committee of Cairo University. Rats received ordinary rat chow, bred. They were housed in properly ventilated wire cages at temperature $\left(24 \pm 1^{\circ} \mathrm{C}\right)$, with normal light/dark cycle. All animals had free access to food and water and followed the same environmental conditions.

\section{Chemicals}

- L-arginine: L-arginine (L-arg.) powder (L-Arginine - reagent grade, $\geq 98 \%$, Sigma Chemical CO., P.O. Box 14508 St. Louis, MO 63178 USA, A-5006 USA).

- Wheat germ oil: Wheat germ oil (WGO) was purchased from El-Captain Company (CAP PHARMA, Al Obor City, Egypt), as a bottle of 30 $\mathrm{ml}$ WGO in a liquid form.

- Chemicals for immunostaining:

- Primary antibodies:

a. Insulin Monoclonal Antibody (ICBTACLS), eBioscience $^{\mathrm{TM}}$ : It is mouse monoclonal antibody (Thermo Fisher Scientific 10255 Science Center Drive San Diego, CA 92121, catalogue number 14-9769-82)

b. Anti iNOS antibody: It is a rabbit polyclonal antibody (Thermo Fisher Scientific 3747 N. Meridian Road Rockford, IL 61105 USA, catalogue number PA1-21054)

- Citrate buffer (cat no AP 9003), Ultravision detection system (Anti-Polyvalent, HRP/ DAB Kit detection system, cat no TP - 015HD) and Mayer's hematoxylin (cat no TA060- MH). All were purchased from Thermo Fisher Scientific, USA.

\section{Preparation of Bone Marrow Derived Mesenchymal Stem Cells from Rats}

Isolation, culture and labeling of MSCs were done at Biochemistry and Molecular Biology Unit at Biochemistry department, Faculty of Medicine, Cairo University, Egypt $^{[10]}$.

MSCs in culture were characterized by their plastic adhesiveness and fusiform shape $\mathrm{e}^{[11]}$.

\section{Immunophenotyping of separated cells}

- Using flow cytometry (Accuri, USA), the MSCs were positive for CD29 (Sigma, USA, SAB 4501582) and negative for CD45 (Sigma, USA, OX-1 84112004) ${ }^{[12]}$

\section{Cell Viability Analysis}

Using trypan blue dye, the viable cells appeared shinny unstained under the microscope, while dead cells appeared blue ${ }^{[13]}$.

\section{Labeling of MSCs with PKH26 dye}

Cultured cells were labeled with fluorescent cell tracker PKH26 (Sigma, USA, MINI26) according to manufacturer's instructions to track their migration and homing $^{[14]}$

\section{Experimental design}

Group I (Control Group (C); no.=12)

This group included three equal subgroups

- Subgroup IA: received $2.5 \mathrm{ml}$ saline (El Fath for Drug and Cosmetics Industry, FIPCO, New Borg Al Arab City, Egypt) by intra peritoneal (I.P.) injection once.

- Subgroup IB: received $2.5 \mathrm{ml}$ saline by I.P. injection once then after $1 \mathrm{~h}$ received $1 \mathrm{ml}$ Phosphate Buffer Saline (PBS) (Sigma Chemical CO.P.3813 USA). by I.P. injection.

- Subgroup IC: received $2.5 \mathrm{ml}$ saline by I.P. injection once then after $1 \mathrm{~h}$ received $3 \mathrm{ml} / \mathrm{kg}$ body weight $(0.6 \mathrm{ml} / \mathrm{rat})$ distilled water by oral gavage every 24 hours for 3 successive days.

- Rats were sacrificed at the same time with Group II.

\section{Group II (Acute Pancreatitis Group (AP); no.=10)}

This group was injected I.P. by $2.5 \mathrm{ml} \mathrm{L-arg.} 20 \%$ concentration $^{[15]}$. They were subdivided into two equal subgroups:

- Subgroup IIA (5 rats): $1 \mathrm{~h}$ after AP induction received $1 \mathrm{ml}$ PBS by I.P. injection.

- Subgroup IIB (5 rats): $1 \mathrm{~h}$ after AP induction received $3 \mathrm{ml} / \mathrm{kg}$ body weight $(0.6 \mathrm{ml} / \mathrm{rat})$ distilled water by oral gavage every 24 hours for 3 successive days.

- Rats were sacrificed on the 4th day after AP induction.

\section{Group III (Bone marrow derived Mesenchymal} Stem Cells Group (BMSCs); no. $=10)$

This group received the same dose of L-arg. as AP group then after $1 \mathrm{~h}$ they were injected I.P. by $1 \mathrm{ml} /$ rat of PKH26 labeled BMSCs (1x106 cells/ ml) suspension in $\mathrm{PBS}^{[16]}$

- Five rats were sacrificed after 24h. to detect BMSCs homing and the rest on the 4th day after AP induction.

\section{Group IV (Wheat Germ Oil Group (WGO); no.=10)}

This group received the same dose of L-arg. as AP group then after $1 \mathrm{~h}$ they received WGO in a daily dose of $3 \mathrm{ml} / \mathrm{kg}$ body weight $(0.6 \mathrm{ml} / \mathrm{rat})$ by oral gavage every 24 hours for 3 successive days ${ }^{[17]}$. 
- Rats were sacrificed on the 4th day after AP induction.

\section{Experimental procedure}

\section{1-Induction of Acute Pancreatitis}

L-arginine $20 \%$ solution was prepared by dissolving $2 \mathrm{~g}$ L-arginine hydrochloride in $8 \mathrm{ml} 0.9 \%$ saline. The $\mathrm{pH}$ was adjusted to 7 and volume was completed to $10 \mathrm{ml}$ with saline. It was prepared in Biochemistry Department, Faculty of Medicine, Cairo University. It was injected I.P. in a dose of $2.5 \mathrm{ml} \mathrm{L}$-arg. $20 \%$ concentration (A dose of $250 \mathrm{mg} / 100 \mathrm{~g}$ body weight, equivalent to $1.25 \mathrm{ml} / 100 \mathrm{~g}$ body weight). Fresh solution was prepared on the day of injection ${ }^{[15]}$. Acute pancreatitis was induced in thirty-five rats. Five rats died within the 1st hour after AP induction and the rest were divided randomly into 3 groups.

\section{2-Treatment of Acute Pancreatitis}

- Treatment with BMSCs: allogeneic PKH26 florescent labeled BMSCs suspension in PBS, were injected I.P. in a dose of $1 \mathrm{ml} / \mathrm{rat}(1 \mathrm{x} 106$ cells/ ml) $1 \mathrm{~h}$ after AP induction ${ }^{[16]}$.

- Treatment with WGO: $1 \mathrm{~h}$ after AP induction WGO in a dose of $3 \mathrm{ml} / \mathrm{kg}$ body weight $(0.6 \mathrm{ml} /$ rat) was given by oral gavage then every $24 \mathrm{~h}$ for 3 successive days ${ }^{[17]}$.

\section{3-Laboratory Investigation}

Blood samples from retro orbital vein were collected $24 \mathrm{~h}$ and on the 4th day after AP induction to assess levels of serum amylase, lipase, interleukin-1B and interleukin-10. They were measured in the Biochemistry Department, Faculty of Medicine, Cairo University.

\section{4-Light microscopic studies}

The animals were sacrificed on the $4^{\text {th }}$ day after AP induction using chloroform inhalation. The pancreas was dissected out, fixed in $10 \%$ formol saline for 24 hours at room temperature, dehydrated in ascending grades of alcohol, cleared in xylene then embedded into paraffin wax (Histology Department, Faculty of Medicine, Cairo University)

Sections of 5 mm thickness were stained with the following stains

a. Hematoxylin and $\operatorname{Eosin}^{[18]}$.

b. Immunohistochemical staining ${ }^{[19]}$ using:

1. Anti inducible Nitric Oxide Synthase (iNOS) antibodies.

2. Anti insulin antibodies.

Immunostaining for iNOS only required pretreatment for antigen retrieval, by boiling for 10 minutes in $10 \mathrm{Mm}$, pH 6 citrate buffer and cooling sections for 20 minutes in room temperature. Sections were incubated with the primary antibodies for 1 hour. Ultravision detection system was used and counterstaining was done using Mayer's hematoxylin.
iNOS and insulin Positive reactions appear as brown cytoplasmic deposits.

\section{c-Fluorescent microscopic study}

Unstained sections of group III were examined by fluorescent microscope (Olympus BX-50 f4, Olympus Optical Co. Ltd., Japan. No.7 MO3285) to detect homing of PKH26 labelled BMSCs. PKH26-labeled Cells appear as red to yellow fluorescence according to the intensity of labeling.

\section{d-Morphometric study: It included}

- Mean area percent of iNOS immuno-expression in iNOS immunostained sections at a magnification of $\times 100$.

- Mean area percent of insulin immuno-expression in insulin immunostained sections at a magnification of $\times 100$.

All measurements were done in 10 non overlapping fields from different sections of each group. Image analysis was done using "Leica Qwin $500 \mathrm{C}$ " software image analysis computer system (Cambridge, England) in image analyzing unit, Histology and cell Biology Department, Faculty of Medicine, Cairo University.

\section{e- Statistical Analysis}

The morphometric and biochemical measurements were expressed as mean \pm standard deviation (SD) and were analysed using the software "SPSS" version 20. This was done using ANOVA followed by "Tuckey" post hoc test. Results were considered significant when $P$ value was $<0.05^{[20]}$.

\section{RESULTS}

\section{General Observation}

Five rats died within the first hour after the intraperitoneal (I.P.) injection of L-arginine and the other rats became less active regaining their activity on the second day.

Thebiochemical, histologicalandimmunohistochemical results of all subgroups of control group were similar. The AP rats in subgroup IIA and IIB also showed the same biochemical, histological and immunohistochemical results. Therefore, they were referred to by group I (control group) and group II (AP group), respectively.

\section{A) Lab Results}

\section{I- Plasma Amylase, Lipase and IL-1ß Levels (Histogram 1 \& 2)}

After $24 \mathrm{~h}$ and on 4th day of AP induction, the mean values of plasma amylase, lipase and IL-1B levels showed significant increase in groups GII, GIII and GIV compared to control. There was significant decrease in these mean values in GIII and GIV when compared with GII while there was significant increase in GIV when compared with GIII. 


\section{II- IL-10 Level (Histogram 3)}

After $24 \mathrm{~h}$ and on 4th day of AP induction, the mean value of plasma IL-10 level showed significant decrease in groups GII, GIII and GIV compared to control. There was significant increase in the mean value of plasma IL-10 level in GIII and GIV when compared with GII while there was significant decrease in GIV when compared with GIII.

\section{B) Histological Results}

\section{Fluorescent Microscope Results}

BMSCs group (GIII) showed the presence of PKH26 labeled stem cells in connective tissue (C.T) septa and pancreatic acini (Figure 1).

\section{Hematoxylin and Eosin Stained Pancreatic Sections}

Control group showed normal structure of the pancreas (Figure 2). The AP group showed disorganized acinar architecture. Some acinar cells appeared apoptotic with dark pyknotic nuclei and deep acidophilic cytoplasm. Other cells show cytoplasmic vacuolations. In addition, there was infiltration with Inflammatory cells (Figure 3). However, the acinar architecture was preserved in the acini surrounding the apparently normal islet (Figure 4). BMSCs Group showed an almost apparently normal pancreatic architecture (Figure 5) while WGO Group showed apparently normal acinar pattern with some distorted acini. Less apical acidophilia was noted in some acinar cells and Few cytoplasmic vacuoles were seen (Figure 6).

\section{Anti-iNOS stained pancreatic sections}

Control group revealed negative immunoreactivity (Figure 7). AP Group showed marked cytoplasmic dark brown granules of most acini. Few islet cells showed immunoreaction (Figure 8). BMSCs Group showed weak cytoplasmic reactivity in acinar cells and few reactive cells mainly in between acini (Figure 9). WGO Group revealed moderate cytoplasmic reactivity in most acini. Few cells, mainly in between acini and few islet cells were immune reactive (Figure 10).

\section{Anti-insulin stained pancreatic sections}

Pancreatic sections of GI, GII, GIII and GIV showed dense brown cytoplasmic immunoreactivity in most cells of the pancreatic islets of Langerhans (Figures 11-14) respectively.

\section{C) Morphometric results}

\section{I-Mean area percent of iNOS immunoreactivity (Table 1)}

The mean area percent of iNOS immunoreactivity in GIII and GIV showed significant decrease when compared to GII, while there was significant increase in GIV when compared with GIII.

\section{II-Mean area percent of insulin immunoreactivity (Table 2)}

There is no significant difference between the mean values of area $\%$ of insulin immunoreactivity in the control and the experimental groups.

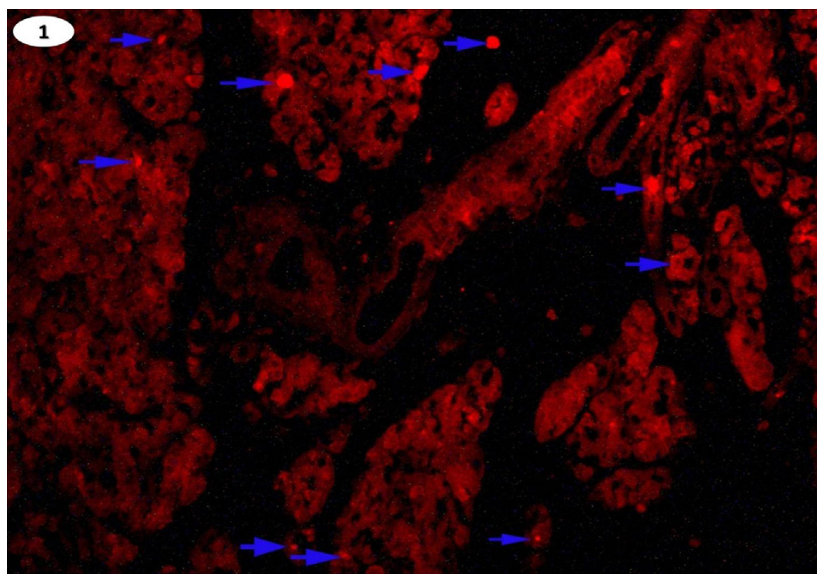

Fig. 1: A photomicrograph of a section in the pancreas of an albino rat from BMSCs group (GIII) showing many red fluorescent PKH26 labeled BMSCs (arrows). (immunoflurescent x 400).

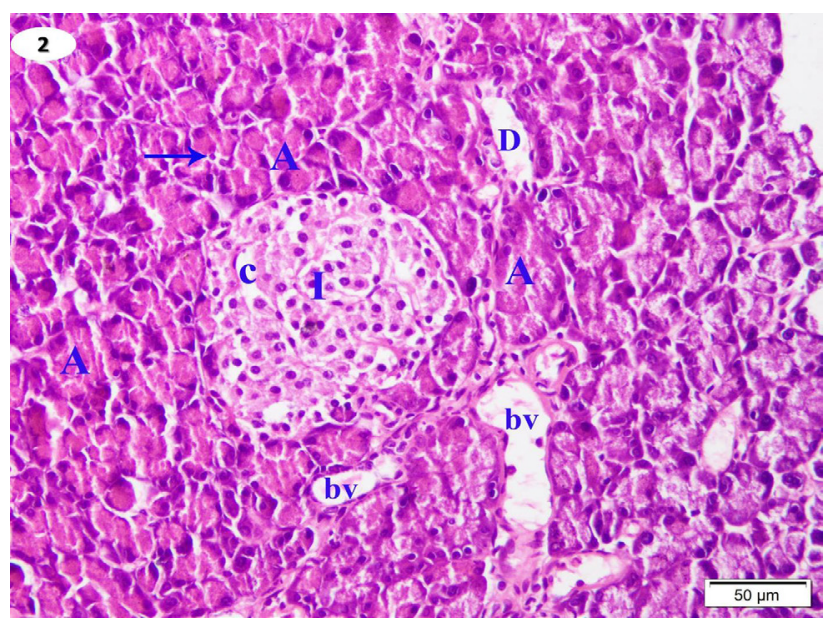

Fig. 2: A photomicrograph of pancreatic section from control group (GI) showing an islet (I) containing capillaries (C) surrounded by pancreatic acini (A). The acini have basal basophilic cytoplasm containing the nuclei and have apical acidophilic granules. Blood vessels (bv), Duct (D) \& centroacinar cell (arrow) are seen. (H\&E x 200)

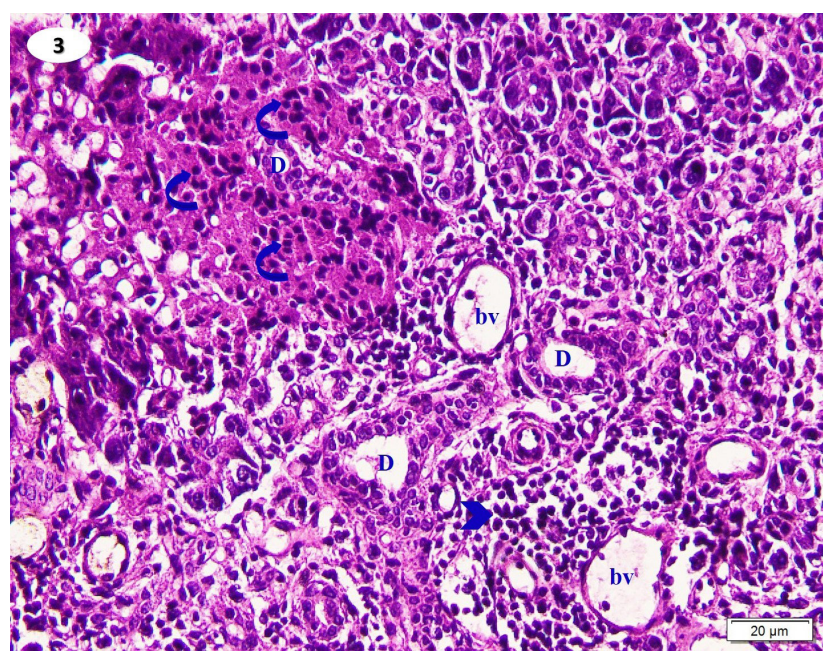

Fig. 3: A photomicrograph of a section in the pancreas from AP group (GII) showing destruction of the normal pancreatic architecture. Many cells appear apoptotic with dark pyknotic nuclei and deep acidophilic cytoplasm (curved arrows), while other cells are vacuolated (V). Inflammatory cell infiltration (arrow head), blood vessels (bv), duct (D) are seen. (H\&E x 200) 


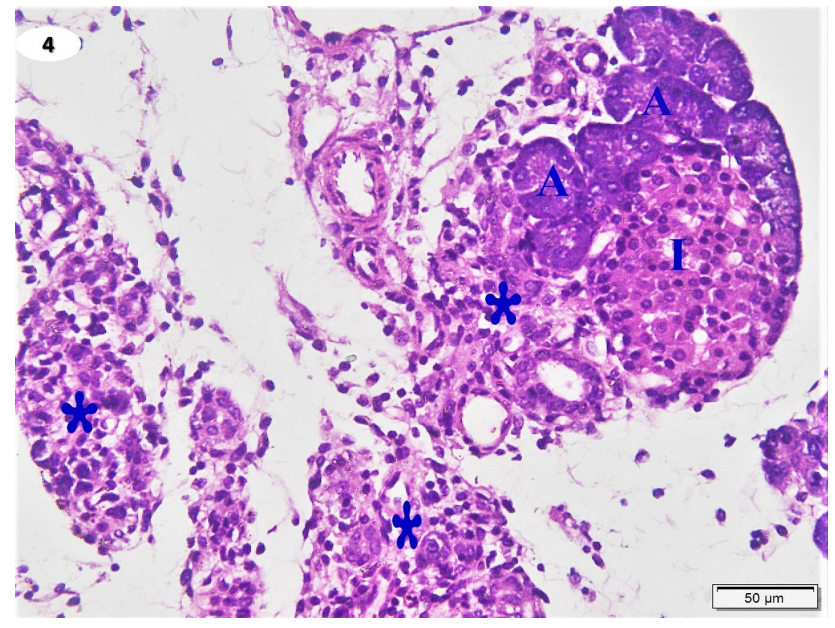

Fig. 4: A photomicrograph of a section in the pancreas of an albino rat from AP group (GII) showing destruction of the normal pancreatic architecture (Asterix) with occasional preservation of some acini (A) surrounding an apparently normal islet of langerhans (I). (H\&E x 200)

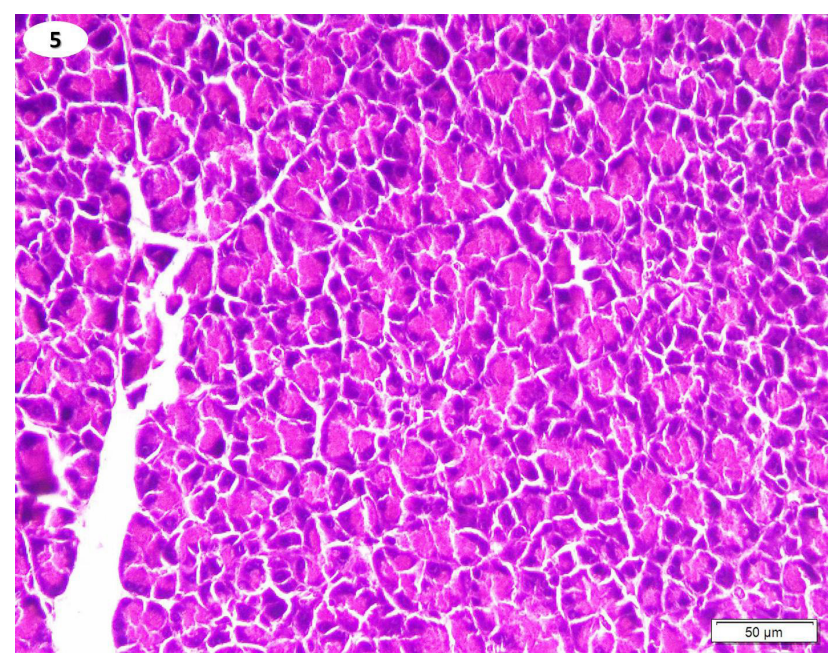

Fig. 5: A photomicrograph of a section in the pancreas of an albino rat from BMSCs treated group (GIII) shows apparently normal architecture of pancreatic acini. (H\&E x 200)

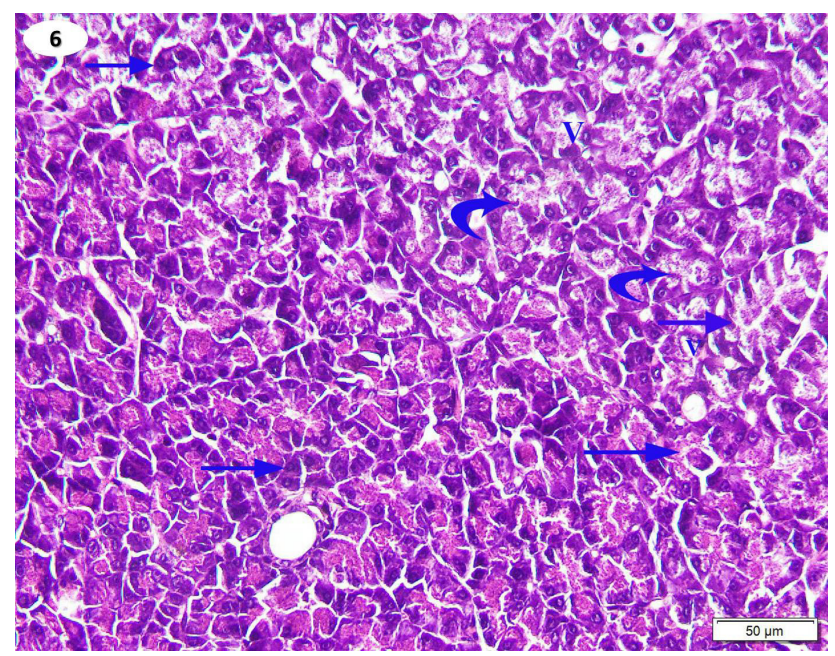

Fig. 6: A photomicrograph of a section in the pancreas of an albino rat from WGO treated group (GIV) shows apparently normal architecture. Some acini are distorted (arrows), others show less apical acidophilia (curved arrows) and few cells appear vacuolated (v). (H\&E x 200)

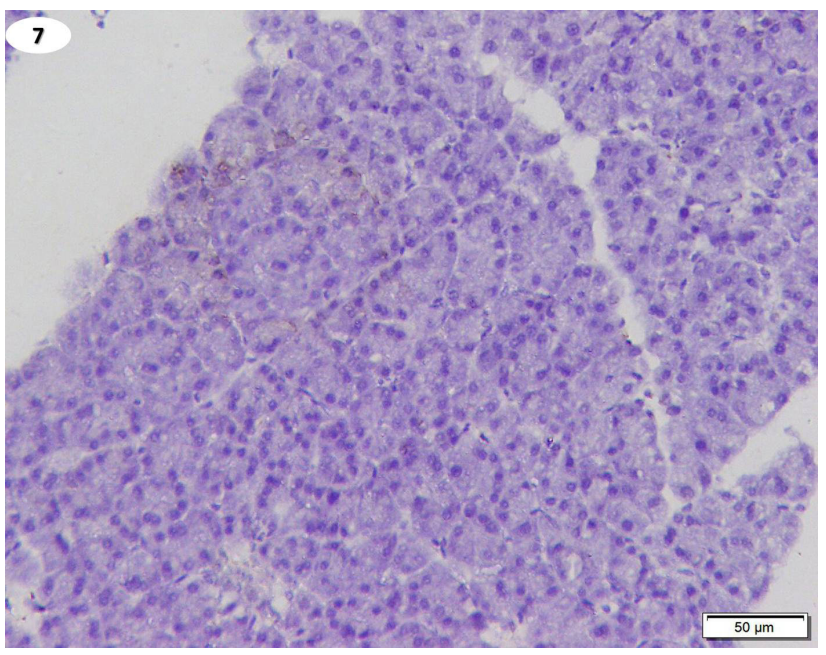

Fig. 7: A photomicrograph of a pancreatic section of control group (GI) showing -ve immunoreactivity for iNOS. (anti iNOS x 200).

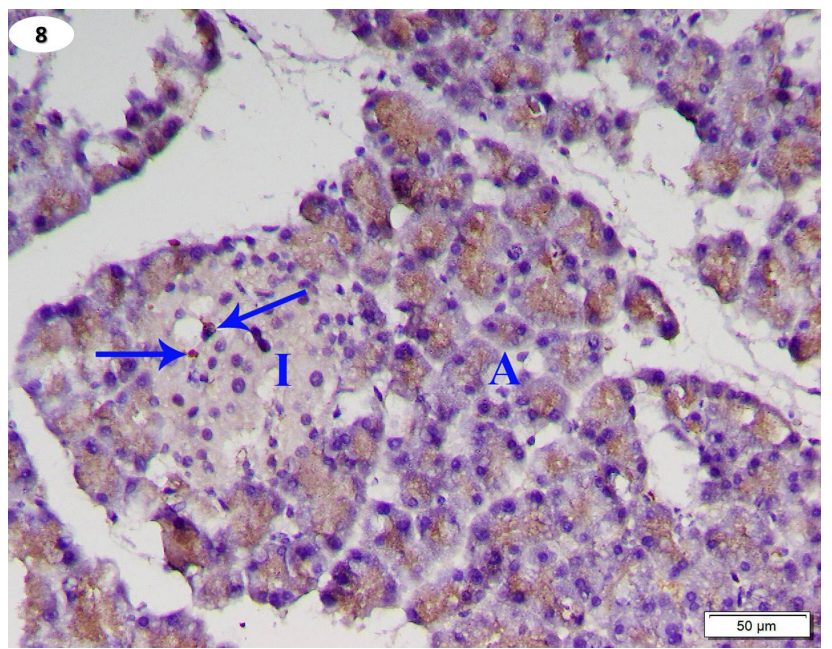

Fig. 8: A photomicrograph of a pancreatic section of AP group (GII) showing strong immunoreactivity for iNOS in most pancreatic acini (A) Few cells in the islet (I) show immune reactivity (arrows). (anti iNOS x 200)

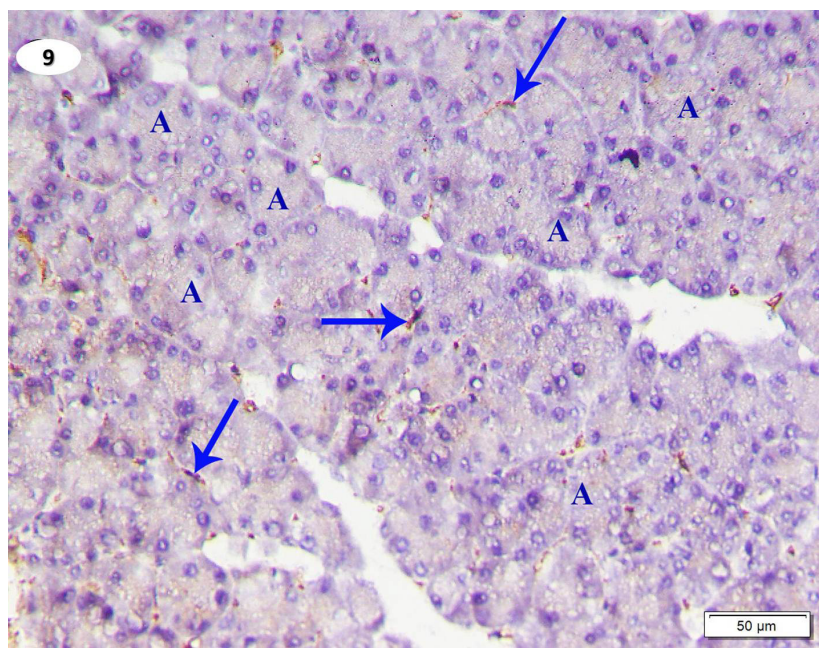

Fig. 9: A photomicrograph of a pancreatic section of BMSCs group (GIII) showing weak immunoreactivity in acinar cells (A) for iNOS. Few immune reactive cells are seen in between acini (arrows). (anti iNOS $x$ 200). 


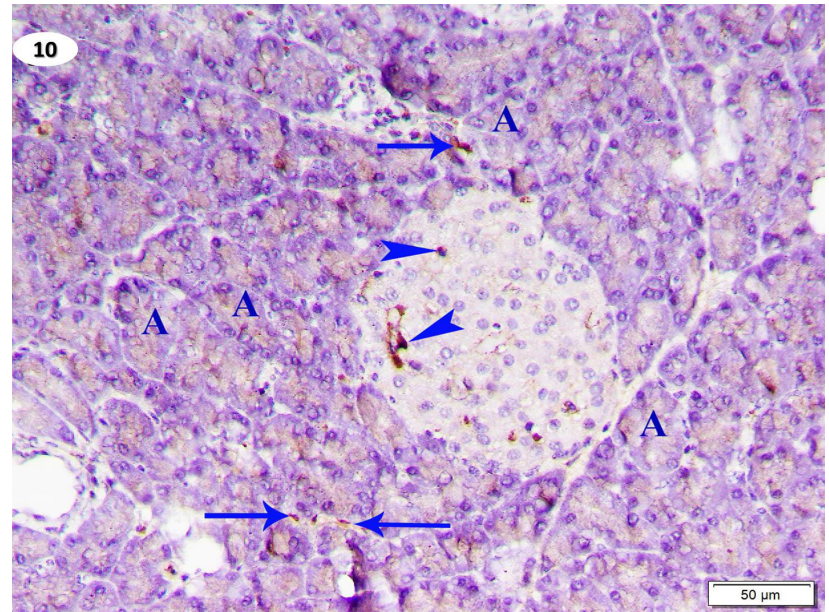

Fig. 10: A photomicrograph of a pancreatic section of WGO group (GIV) showing moderate immunoreactivity for iNOS in most pancreatic acin (A). Few islet cells are immune reactive (arrow heads). Few immune reactive cells are seen in between the acini (arrows). (anti iNOS x 200).

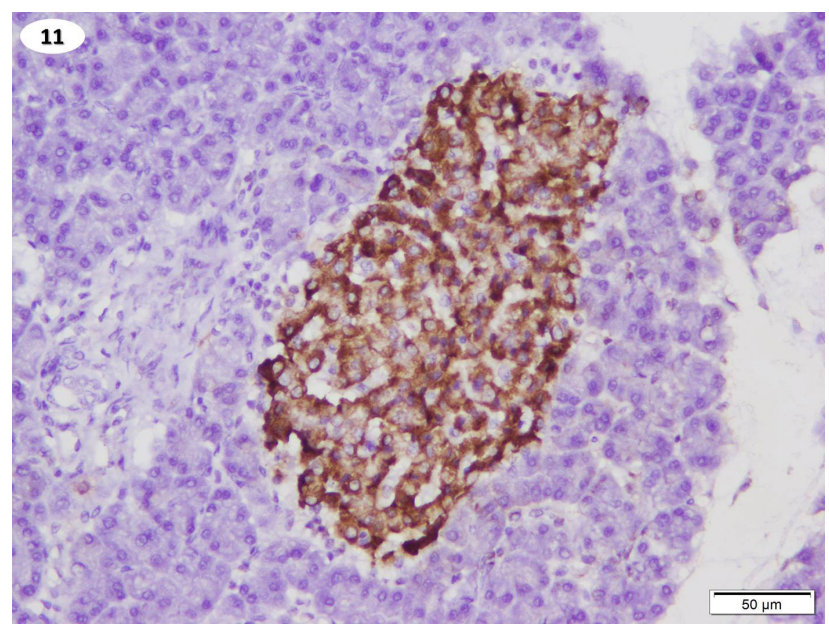

Fig. 11: A photomicrograph of a pancreatic section of control group (GI) showing dense cytoplasmic immunoreactivity in one islet of Langerhans. The immunoreactivity is observed in most islet cells. (Anti-insulin Immunostaining x 200).

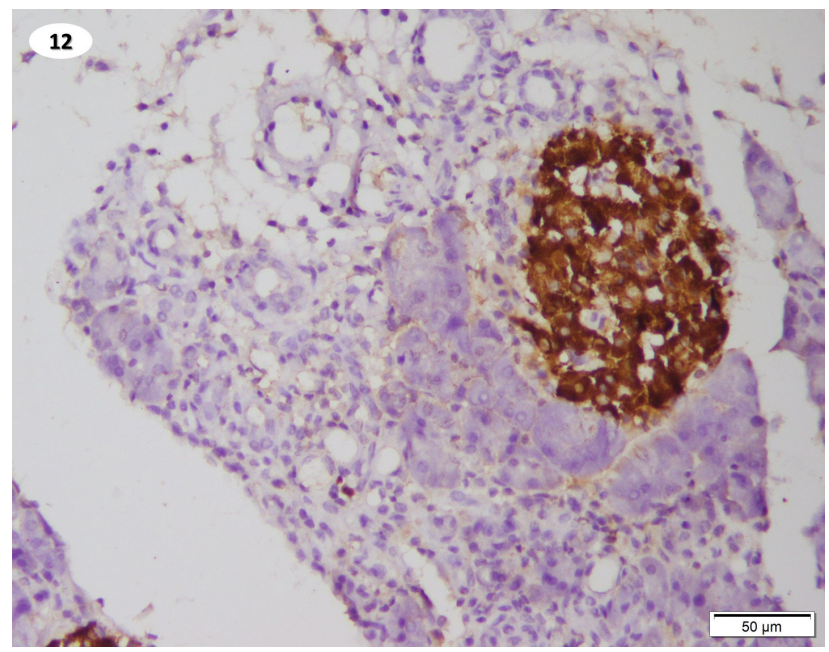

Fig. 12: A photomicrograph of a pancreatic section of AP group (GII) showing dense cytoplasmic immunoreactivity in one islet of Langerhans. The immunoreactivity is observed in most islet cells. (Anti-insulin Immunostaining $\mathrm{x} 200$ ).

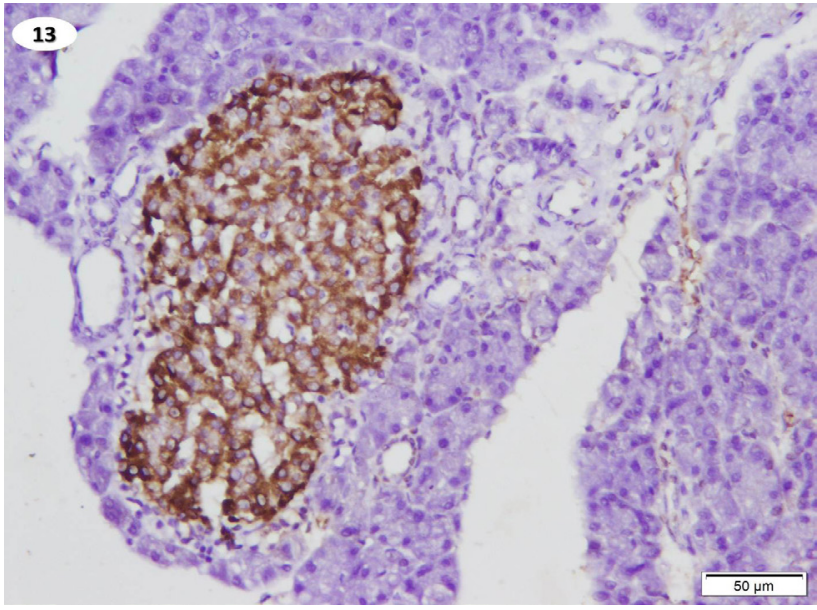

Fig. 13: A photomicrograph of a pancreatic section of AP group (GIII) showing dense cytoplasmic immunoreactivity in one islet of Langerhans. The immunoreactivity is observed in most islet cells. (Anti-insulin Immunostaining x 200).

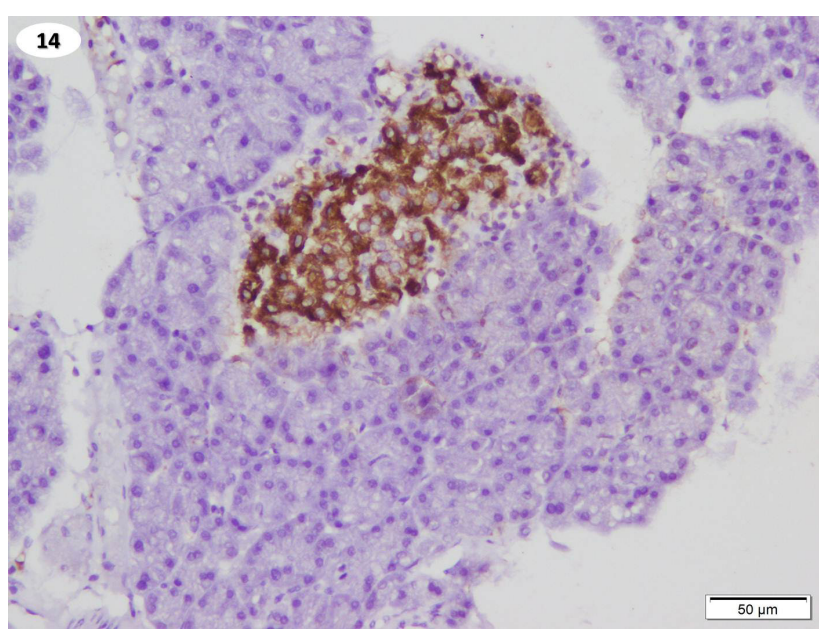

Fig. 14: A photomicrograph of a pancreatic section of AP group (GIV) showing dense cytoplasmic immunoreactivity in one islet of Langerhans. The immunoreactivity is observed in most islet cells. (Anti-insulin Immunostaining x 200).

Table 1: The mean values $( \pm \mathrm{SD})$ of area $\%$ of iNOS immunoreactivity in experimental groups.

\begin{tabular}{cc}
\hline Group & Mean \pm SD \\
\hline GII & $30.1 \pm 2.3$ \\
GIII & $7.04 \pm 0.8^{\star}$ \\
GIV & $10.8 \pm 0.9^{\star \bullet}$ \\
\hline
\end{tabular}

- there is significant decrease when compared with GII.

- there is significant increase when compared with GIII

Table 2: The mean values $( \pm \mathrm{SD})$ of area $\%$ of insulin immunoreactivity in control and experimental groups.

\begin{tabular}{cc}
\hline Group & Mean \pm SD \\
\hline GI & $50.3( \pm 4.9)$ \\
GII & $47.5( \pm 3.2)$ \\
GIII & $51.4( \pm 3.8)$ \\
GIV & $51.2( \pm 2.8)$ \\
\hline
\end{tabular}




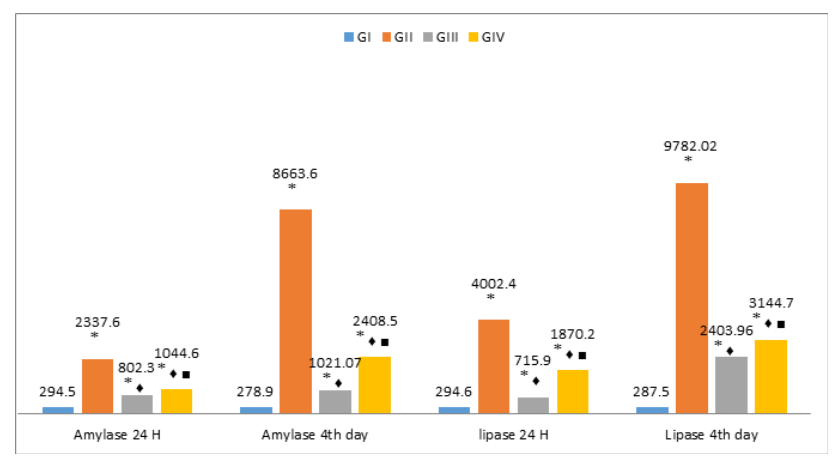

Histogram 1: The mean values of plasma Amylase \& Lipase levels of control and experimental groups $24 \mathrm{~h}$ and 4 th day after AP induction

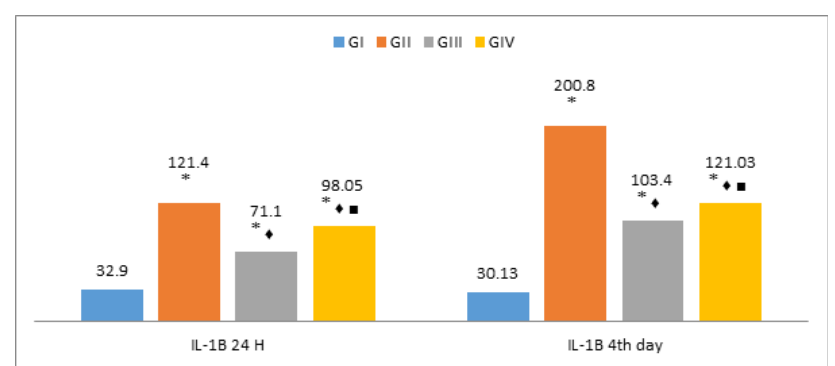

Histogram 2: The mean values of plasma IL-1B level of control and experimental groups $24 \mathrm{~h}$ and $4^{\text {th }}$ day after AP induction

The mean difference is significant at the 0.05 level.

* Significant increase when compared with GI.

- Significant decrease when compared with GII.

- Significant increase when compared with GIII.

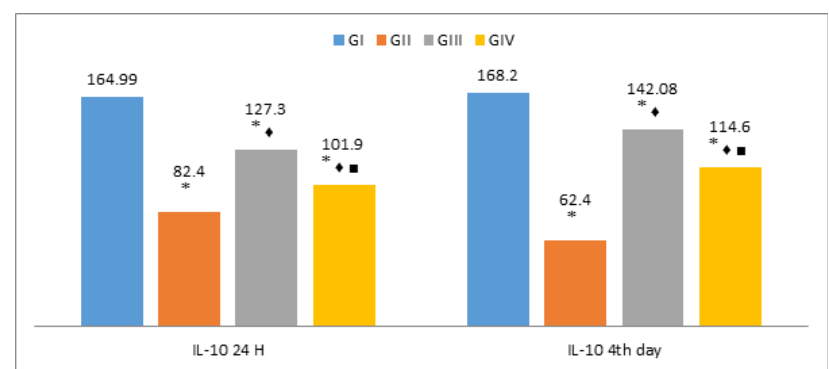

Histogram 3: The mean values of plasma IL-10 level of control and experimental groups $24 \mathrm{~h}$ and 4 th day after AP induction

The mean difference is significant at the 0.05 level.

* Significant increase when compared with GI.

- Significant decrease when compared with GII.

- Significant increase when compared with GIII

\section{DISCUSSION}

The current study induced experimental AP in rats by using a single I.P injection of L-arginine in a dose of $250 \mathrm{mg} / 100 \mathrm{~g}$ body weight. This is in accordance with El-Rahman et al. (2011) ${ }^{[21]}$ and Hasan et al. (2015) ${ }^{[22]}$. L-arginine produces biochemical and histological changes like that of human $\mathrm{AP}^{[23]}$. It distorts the membranes of zymogen granules and release their enzymes to the interstitium causing inflammation ${ }^{[22]}$. Time of scarification was chosen according to Moreira et al., 2011 ${ }^{[24]}$ who stated that peak histological changes were observed around $72 \mathrm{~h}$ after induction of AP.

In this study, the mortality rate in the 1 st hour after AP induction in GII (AP), GIII (BMSCs) and GIV (WGO) was $14.3 \%$. The Overall mortality in AP is about $3 \%-6 \%$. Whereas, it reaches $30 \%$ in severe acute pancreatitis (SAP) due to absence of specific treatment ${ }^{[25]}$.

The pancreatic enzymes derived from pancreatic acini (amylase, lipase, and the proenzyme trypsinogen) are considered the main diagnostic parameters of $\mathrm{AP}^{[26]}$. In this study, there was significant elevation in serum amylase and lipase $24 \mathrm{~h}$ and on $4^{\text {th }}$ day following AP induction in AP group as compared with control group. These findings are in accordance with Abdin et al., 2010 [27],

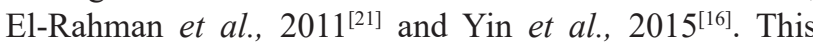
may be due to membrane disruption of zymogen granules secondary to increased free radicals leading to release of amylase and lipase into interstitium ${ }^{[28]}$. It also, could be secondary to elevation of inflammatory cytokines and lipid peroxidation ${ }^{[29]}$. Shah et al., 2010 ${ }^{[30]}$ mentioned that, the serum amylase in AP elevates within 6 hours of AP onset and remains elevated for 3-5 days. Lippi et al., 2012 $2^{[31]}$ stated that serum lipase elevates within 3-6 hours of AP onset and remains elevated for around 7-14 days.

In the present work, there was significant elevation in serum IL-1 $\beta 24 \mathrm{~h}$ and on $4^{\text {th }}$ day after AP induction in the AP group as compared with control group. This agrees with Jung et al., 2015 ${ }^{[32]}$ who observed the increase in proinflammatory cytokines in SAP, such as TNF-a, IL-1 $\beta$, IL-6, and other inflammatory mediators, including iNOS. $\mathrm{Xu}$ et al $2014^{[33]}$ stated that IL-1 $\beta$ activates trypsin and impairs autophagy by changing the intracellular calcium leading to decrease in the viability of acinar cells. Autophagy includes lysosome-mediated processing, elimination of damaged proteins, organelles or microorganisms ${ }^{[5]}$. Grasso et al., 2011 ${ }^{[34]}$ considered autophagy as a protective process that damages harmful activated zymogens during early pancreatitis. On the other hand, Hashimoto et al., $2008^{[35]}$ suggested that autophagy damages acinar cells by delivering trypsinogen to the lysosomes, which activate it to trypsin. Mareninova et al., 2009 ${ }^{[36]}$ showed that impaired autophagy is associated with imbalance between degradation and activation of trypsinogen, leading to intra-acinar accumulation of active trypsin. Moreover, autophagy in acute pancreatitis includes degradation of damaged mitochondria in a process called Mitophagy ${ }^{[37]}$.

In this study, serum IL-10 was reduced $24 \mathrm{~h}$ and on $4^{\text {th }}$ day after AP induction in the AP group as compared with control group. This was in accordance with Liu et al., $2014^{[38]}$ who found decrease in serum IL-10 in ceruleininduced SAP mice. IL-10 is anti-inflammatory cytokine that correlates with the severity of pancreatitis. It decreases the inflammatory cytokines, serum amylase, serum lipase, edema, necrosis and hemorrhage in AP. Moreover, IL-10 can improve the severity of caerulein-induced AP when given as prophylaxis and treatment ${ }^{[4}$ and 39$]$. 
MSCs could repair tissues in acute diseases and have shown improving effects on different acute injuries ${ }^{[40]}$. In this study, using BMSCs in GIII significantly decreased both plasma amylase and lipase levels after $24 \mathrm{~h}$ and on $4^{\text {th }}$ day. This was coincident with Yin et al., 2015 ${ }^{[16]}$ and $\mathrm{Qu}$ et al., 2017[6]. Transplanted BMSCs could develop into pancreatic cells in vivo. Moreover, they could reduce inflammation by decreasing cytokines in $\mathrm{AP}^{[41}$ and ${ }^{32]}$. In BMSCs treated group, serum IL-1 $\beta$ was significantly declined $24 \mathrm{~h}$ and 4 days after AP induction as compared with AP group. These results are in line with the study of Meng et al., 2013 ${ }^{[42]}$ who demonstrated that human BMSCs decreased the level of IL-1 $\beta$ in SAP. In addition, Tu et al., $2012^{[41]}$ showed the same finding by using umbilical cordderived MSCs. Jung et al., 2015 ${ }^{[32]}$ suggested that human BMSCs improve SAP secondary to its anti-inflammatory effect. Treatment with BMSCs in GIII was associated with significant elevation of serum IL-10 $24 \mathrm{~h}$ and on $4^{\text {th }}$ day after AP induction as compared with AP group. This was in accordance with Tu et al., 2012 ${ }^{[41]}$ who found that treatment with BMSCs suppressed the high level of TNF and IL- 6 but increased that of IL-10 in SAP.

Until now, the role of WGO in L-Arginine-induced AP has not been reported except for the study done by AbdelGawad, 2015 ${ }^{[17]}$. In the current study using WGO in the treatment of AP decreased levels of both serum amylase and lipase $24 \mathrm{~h}$ and on $4^{\text {th }}$ day after AP induction but these results disagreed with Abdel-Gawad, 2015 ${ }^{[17]}$ who found that increased serum lipase activity after $24 \mathrm{~h}$ was not affected by treatment with WGO. In addition, in WGO treated group (GIV) there was significant reduction in IL$1 \beta$ as compared with AP group, which is in line with AbdelGawad, 2015 ${ }^{[17]}$ who found that WGO treatment decreased the elevated level of pancreatic IL-1 $\beta$ in the treated group. Treating with WGO caused elevation in serum IL-10 24h and on $4^{\text {th }}$ day after AP induction. This could be due to the high content of vitamin $\mathrm{E}$ in WGO that was in line with Xiong et al., 2014 ${ }^{[43]}$ who indicated that vitamin E significantly increased the level of IL 10 in arthritis in rats. In addition, this result agreed with EL-Feki et al., $2016^{[44]}$ who observed that Pre-treatment with vitamin $\mathrm{E}$ increased IL-10 level in hepatotoxicity in rats. Wheat germ oil can reduce oxidative stress through vitamin $\mathrm{E}$ that protects DNA and cell membrane from oxidative damage. Furthermore, wheat germ oil has anti-inflammatory effects through Omega-3 unsaturated fatty acids ${ }^{[45 \& 46]}$.

In the current study, detection of I.P. injected BMSCs labeled with PKH26 fluorescent dye $24 \mathrm{~h}$ after AP induction in pancreatic tissue indicates homing of these cells into the pancreas. On contrary Dong et al., $2018^{[47]}$ found nearly no BMSCs in pancreas after its I.P. injection while they found more BMSCs after its injection either through tail vein or through both tail vein and peritoneum. However, they suggested that the protective role of I.P injected BMSCs was done without homing to pancreas through a paracrine effect. MSCs could secret some anti-inflammatory cytokines in a paracrine manner. For example, they secret interleukin 10, insulin-like growth factor (IGF-1) and vascular endothelial growth factor ${ }^{[48 \& 49]}$.

Histological examination of HandE stained pancreatic sections of AP group showed disturbed acinar architecture with inflammatory cell infiltration. Apoptotic cells with dark pyknotic nuclei and deep acidophilic cytoplasm were also seen. These results were in accordance with $\mathrm{Qu}$ et al., $2017^{[6]}$ who found structural distortion, inflammatory cell infiltration, hemorrhage and necrosis in AP. In addition, Jung et al., 2015 $5^{[32]}$ found marked inflammation, edema and necrosis in AP group.

The apoptosis of pancreatic acinar cells is secondary to inflammation induced by L-arginine. This might be due to metabolic changes in the endoplasmic reticulum and inhibited synthesis of nucleic acids. In addition, it could be due to disturbance of protein synthesis due to decreased polyamine synthesis. Moreover, L-arginine can produce excess nitric oxide (NO) leading to vascular dilatation, blood stasis and inflammatory infiltration. Furthermore, oxygen free radicals and inflammatory cytokines are involved in the acti $\neg$ vation of L-arginine induced $\mathrm{AP}^{[50 \& 16]}$.

In this study cytoplasmic vacuolations were detected which agreed with the results of El-Rahman et al., 2011[21] who found multiple vacuoles within pancreatic acinar cells. Mareninova et al., 2009 ${ }^{[36]}$ suggested that these vacuoles were due to disturbed autophagy occurred in AP. Autophagy was caused by decreased lysosomal degradation secondary to imbalance between cathepsin $\mathrm{L}$ and cathepsin B. Cathepsin L degrades trypsinogen and trypsin while cathepsin B converts trypsinogen into trypsin. Finally, this imbalance leads to intra-acinar accumulation of active trypsin. Ropolo, $2007^{[51]}$ suggested that during AP, a transmembrane protein called Vacuole Membrane Protein 1(VMP1) was highly expressed in acinar cells leading to numerous cytoplasmic vacuoles.

In this study, the acinar architecture was intact in the acini surround the islet, which was in line with AbdelGawad, 2015 ${ }^{[17]}$. Moreover, it agreed with Hegyi et al., $2004^{[52]}$ who observed that acinar cells surrounding the islets of Langerhans remained intact. To confirm their finding, they induced pancreatitis in diabetic rats and found that, acini surrounding islets did not remain intact. They also found decreased pancreatic regenerative response to exogenous cholecystokinin (CCK-8) and explained that by the low insulin level. Moreover, they found no histological difference between the acini surrounding the islets and that far from it. Their findings confirmed the role of insulin in the regulation of the exocrine pancreatic structure.

In this study, treating with stem cells caused improvement in the HandE stained pancreatic sections in BMSCs treated group showing an almost normal pancreatic architecture. Most of the acini appeared normal with basal basophilia and apical acidophilia as well as apparently normal zymogen granules. This was in accordance with Zhao et al, 2016 $6^{[53]}$ who found that after BMSCs 
transplantation, the pancreatic necrosis and inflammation were significantly improved. Jung et al., 2011 ${ }^{[40]}$ and Meng et al., 2013 ${ }^{[42]}$ have reported that human BMSCs and human umbilical cord-derived MSCs, decrease serum and pancreatic levels of pro-inflammatory cytokines and increase anti-inflammatory cytokines. Yang et al., 2013 ${ }^{[54]}$ stated that umbilical cord MSCs transplanted immediately after induction of AP showed a better anti-inflammatory effect than those transplanted several hours after induction. Jung et al., 2015 $5^{[32]}$ and Kawakubo et al., 2018 ${ }^{[55]}$ reported that the anti-apoptotic and anti-inflammatory effect of BMSCs could occur through several molecules secreted by MSCs. Yin et al., 2016 ${ }^{[56]}$ showed that micro vesicles from BMSCs attenuated injury of AP. He et al., 2016 ${ }^{[57]}$ and Zhao et al., 2016 $6^{[53]}$ have described that BMSCs could migrate to several organs including the pancreas.

Examining sections of the WGO treated group showed improvement in the histological picture in the form of apparently normal acinar pattern with some distorted acini. Some acini showed less apical acidophilia in the acinar cells. These results agreed with Abdel-Gawad, $2015^{[17]}$ who found that WGO improved L-arginine-induced AP through its anti-inflammatory effect which might be through inhibiting the release of inflammatory cytokine IL-1 $\beta$.

In current study immunohistochemical examination for iNOS showed its increased expression in AP group as compared with control group and that agrees with Choi et al., 2016 $6^{[58]}$ who found that the iNOS was markedly expressed in mice at $72 \mathrm{~h}$ after induction of pancreatitis by 1 -arginine. Moreover, few immune reactive cells were seen in between the acini, this come in line with Buchwalow et al., 2013 ${ }^{[59]}$ who found increased iNOS expression in pancreatitis with strong immunostained infiltrating inflammatory cells adjacent to the affected areas. Nitric oxide is one of reactive nitrogen species associated with oxidative stress that plays a principle role in AP. Nitric Oxide could have a beneficial effect, however, its over production could be very harmful ${ }^{[60]}$.

Nitric oxide plays an important role in signaling, proliferation, survival, and death of both normal and transformed cells ${ }^{[61]}$. Nitric oxide synthase (NOS) enzyme produces nitric oxide in cells by converting l-arginine into 1-citrulline and $\mathrm{NO}^{[62]}$. There are three NOS isoforms encoded by three different genes. The constitutive (cNOS) and $\mathrm{Ca}+2$-dependent isoforms include neuronal (nNOS) encoded by NOS1gene. The endothelial (eNOS) encoded by NOS3 gene. The $\mathrm{Ca}+2$-independent inducible nitric oxide synthase (iNOS) encoded by NOS2 gene. Inducible nitric oxide synthase is induced by inflammatory cytokines, endotoxin and hypoxia ${ }^{[61]}$. Constitutive cNOS generates $\mathrm{NO}$ in little concentration in physiological conditions, while iNOS can produce $\mathrm{NO}$ at much higher concentration with sustained activity in pathological conditions ${ }^{[63]}$.

In this study, treatment with BMSCs markedly reduced the iNOS expression as confirmed by significant decrease in iNOS area percent in BMSCs treated group when compared with AP group. This was in line with yang et al., 2015 ${ }^{[64]}$ who indicated the beneficial effect of BMSCs derived extracellular vesicles (EVs) through decreasing the proinflammatory mediators such as TNF- $\alpha$ and iNOS. They stated that, the expression of iNOS and TNF- $\alpha$ significantly decreased in colitis after treatment with BMSC-EVs. Jung et al., 2015 ${ }^{[32]}$ suggested that human BMSCs improved SAP by its anti-inflammatory effect. Inan et al., 2017 ${ }^{[65]}$ hypothesized that MSC homed to the site of injury in intestinal ischemia/reperfusion model and decreased oxidative stress. They explained this anti-oxidative effect by decreasing oxygen radicals and pro-inflammatory cytokines meanwhile increasing antiinflammatory cytokines.

In this study, treatment with WGO reduced the iNOS expression as confirmed by significant decrease in iNOS area $\%$ in WGO group compared with AP group. This was to a lesser extent than BMSCs as confirmed by significant increase in iNOS area \% in WGO group when compared with BMSCs group. This result come in line with Akool., 2015 ${ }^{[66]}$ who found that administration of WGO significantly reduced iNOS expression in cyclosporin A -induced hepatotoxicity in rats. He mentioned that WGO could restore the balance between oxygen radical production and endogenous antioxidant defense system that was disturbed by cyclosporin A.

In this study, immunohistochemical examination for insulin revealed no affection to the islets of Langerhans in the AP, BMSCs and WGO groups as they showed positive reaction like that of the control group. This was confirmed by nonsignificant difference in insulin area percent between the control and the experimental groups. This result come in line with Kovalska et al., 2012 $2^{[67]}$ who found that the microscopic structure of the islets of Langerhans was intact among masses of debris in patients with acute necrotizing pancreatitis. In addition, staining with Masson showed a net of fibrin surrounding the islets of Langerhans that protected its structure in patients with acute necrotizing pancreatitis.

\section{CONCLUSION}

In this study, the improving effect of BMSCs on AP was superior to the effect of WGO as confirmed by biochemical, histological and immunohistochemical methods.

\section{CONFLICT OF INTEREST}

There are no conflicts of interest

\section{REFERENCES}

1. Forsmark CE and Baillie J: AGA Institute technical review on acute pancreatitis in Gastroenterology. (2007) 132(5): 2022-2044.

2. Petrov MS, Shanbhag S, Chakraborty M, Phillips AR and Windsor JA: Organ failure and infection of pancreatic necrosis as determinants of mortality in patients with acute pancreatitis in Gastroenterology. (2010) 139(3): 813-820. 
3. Greenberg JA, Hsu J, Bawazeer M, Marshall J, Friedrich JO, Nathens A, Coburn N, May GR Pearsall E and McLeod RS: Clinical practice guideline: management of acute pancreatitis in Canadian Journal of Surgery. (2016) 59(2):128.

4. Kambhampati S, Park W and Habtezion A: Pharmacologic therapy for acute pancreatitis in World journal of gastroenterology. (2014) 20(45): 16868.

5. Singh $\mathrm{P}$ and Garg PK: Pathophysiological mechanisms in acute pancreatitis: Current understanding in Indian Journal of Gastroenterology. (2016) 35(3): 153-166.

6. Qu B, Chu Y, Zhu F, Wang B, Liu T, Yu B and Jin S: Granulocyte colony-stimulating factor enhances the therapeutic efficacy of bone marrow mesenchymal stem cell transplantation in rats with experimental acute pancreatitis in Oncotarget. (2017) 8(13): 21305-21314.

7. Hao L, Sun H, Wang J, Wang T, Wang M and Zou $Z$ : Mesenchymal stromal cells for cell therapy: besides supporting hematopoiesis in International journal of hematology. (2012) 95(1): 34-46.

8. Sun T, Gao GZ, Li RF, Li X, Li DW, Wu SS, Yeo $\mathrm{AE}$ and Jin B: Bone marrow-derived mesenchymal stem cell transplantation ameliorates oxidative stress and restores intestinal mucosal permeability in chemically induced colitis in mice in American journal of translational research. (2015) 7(5): 891.

9. Ghafoor K, Özcan MM, AL-Juhaımı F, Babıker EE, Sarker ZI, Ahmed IAM and Ahmed MA: Nutritional composition, extraction, and utilization of wheat germ oil: A review in European Journal of Lipid Science and Technology. (2017) 119 (7): 1-9

10. Alhadlaq A and Mao JJ: Mesenchymal stem cells: isolation and therapeutics in Stem cells and development. (2004) 13(4): 436-448.

11. Rochefort YG, Vaudin P, Bonnet N, Pages JC, Domenech J, Charbord $\mathrm{P}$ and Eder V: Influence of hypoxia on the domiciliation of mesenchymal stem cells after infusion into rats: possibilities of targeting pulmonary artery remodeling via cells therapies? in Respiratory Research. (2005) 6(1): 125 .

12. Ode A, Kurtz A, Schmidt-Bleek K, Schrade P, Kolar P, Buttgereit F, Lehmann K, Hutmacher DW, Duda GN and Kasper G: CD73 and CD29 concurrently mediate the mechanically induced decrease of migratory capacity of mesenchymal stromal cells in European Cells and Materials. (2011) 22: 26-42.
13. Louis KS and Siegel AC: Cell viability analysis using trypan blue: manual and automated methods in Methods Mol. Biol. (2011) 740: 7- 12.

14. Kyriakou C, Rabin N, Pizzey A, Nathwani A and Yong K: Factors that influence short-term homing of human bone marrow-derived mesenchymal stem cells in a xenogeneic animal model in Haematologica (2008) 93: 1457- 1465

15. Dawra R and Saluja AK: L-arginine-induced experimental acute pancreatitis in Pancreapedia: The Exocrine Pancreas Knowledge Base. (2012) Version 1.0:1-8. DOI: 10.3998/panc.2012.6.

16. Yin $\mathrm{G}, \mathrm{Hu} \mathrm{G}$, Wan R, Yu G, Cang X, Ni J, Xiong $\mathrm{J}, \mathrm{Hu} \mathrm{Y}$, Xing M, Fan Y and Xiao W: Role of bone marrow mesenchymal stem cells in L-arginduced acute pancreatitis: effects and possible mechanisms in International journal of clinical and experimental pathology. (2015) 8(5): 4457.

17. Abdel-Gawad SK: Therapeutic and Protective Effect of Wheat Germ Oil on L-arginine Induced Acute Pancreatitis in Adult Albino Rats in Journal of Cell Science and Therapy. (2015) S8: 1-7.

18. Kiernan J: Histological and histochemical methods: theory and practice. $3^{\text {rd }}$ ed., Arnold publisher. London, New York and New Delhi. (2001) pp: $111-162$.

19. Bancroft $\mathrm{J}$ and Gamble M: Theory and Practice of Histological Techniques. $7^{\text {th }}$ ed., staining methods, Churchill Livingstone, Edinburgh, London, Madrid, Melbourne, New York and Tokyo. (2008) pp: $263-325$

20. Emsley R, Dunn G and White IR: Mediation and moderation of treatment effects in randomised controlled trials of complex interventions in Stat Methods Med Res (2010) 19: 237- 270.

21. El-Rahman AA, Mishriki ES, Shehab AA and Mona AA: Therapeutic effect of pentoxifylline versus losartan on experimentally induced acute pancreatitis in adult albino rats: light and electron microscopic study in Egyptian Journal of Histology. (2011) 34(3): 606-619.

22. Hasan MI, Bakr AG and Shalkami AGS: Modulation of 1-arginine-induced acute pancreatitis by meloxicam and/or 1-carnitine in rats in Int $\mathrm{J}$ Basic Clin Pharmacol. (2015) 4: 1247-1253.

23. Aziz NM, Kamel MY and Rifaai RA: Effects of hemin, a heme oxygenase-1 inducer in L-arginineinduced acute pancreatitis and associated lung injury in adult male albino rats in Endocrine regulations. (2017) 51(1), 20-30.

24. Moreira M, Matias JEF, Souza CJFD, Nicoluzzi JEL, Caron PE and Repka JCD: Action of tacrolimus in arginine induced experimental acute pancreatitis in Revista do Colégio Brasileiro de Cirurgiões. (2011) 38(4): 260-265. 
25. Dumnicka $P$, Maduzia $D$, Ceranowicz $P$, Olszanecki R, Drożdż R and Kuśnierz-Cabala B: The interplay between inflammation, coagulation and endothelial injury in the early phase of acute pancreatitis: Clinical implications in International journal of molecular sciences. (2017) 18(2): 354.

26. Viljoen A and Patrick JT: In Search for a Better Marker of Acute Pancreatitis - Third Time Lucky? In Clinical Chemistry. (2011) 57(11): 1471-1473.

27. Abdin AA, El-Hamid MAA, El-Seoud SHA and Balaha MF: Effect of pentoxifylline and/or alpha lipoic acid on experimentally induced acute pancreatitis in European journal of pharmacology. (2010) 643(2-3): 289-296.

28. Rattan SI: Theories of biological aging: genes, proteins, and free radicals in Free radical research. (2006) 40(12): 1230-1238.

29. Szabolcs A, Reiter RJ, Letoha T, Hegyi P, Papai G, Varga I, Jarmay K, Kaszaki J, Sari R, Rakonczay $\mathrm{Jr} \mathrm{Z}$ and Lonovics J: Effect of melatonin on the severity of L-arginine-induced experimental acute pancreatitis in rats in World journal of gastroenterology. (2006) 12(2):251.

30. Shah AM, Eddi R, Kothari ST, Maksoud C, DiGiacomo WS and Baddoura W: Acute pancreatitis with normal serum lipase: a case series in Journal of the Pancreas. (2010) 11(4): 369-72.

31. Lippi G, Valentino M and Cervellin G: Laboratory diagnosis of acute pancreatitis: in search of the Holy Grail in Critical reviews in clinical laboratory sciences. (2012) 49(1): 18-31.

32. Jung KH, Yi T, Son MK, Song SU and Hong SS: Therapeutic effect of human clonal bone marrowderived mesenchymal stem cells in severe acute pancreatitis in Archives of pharmacal research. (2015) 38(5): 742-751.

33. Xu B, Bai B, Sha S, Yu P, An Y, Wang S, Kong X, Liu C, Wei N, Feng Q and Zhao Q: Interleukin$1 \beta$ induces autophagy by affecting calcium homeostasis and trypsinogen activation in pancreatic acinar cells in International journal of clinical and experimental pathology. (2014) 7(7): 3620 .

34. Grasso D, Ropolo A, Ré AL, Boggio V, Molejón MI, Iovanna JL, Gonzalez CD, Urrutia R and Vaccaro MI: Zymophagy, a Novel Selective Autophagy Pathway Mediated by VMP1USP9x-p62, Prevents Pancreatic Cell Death in The Journal of Biological Chemistry. (2011)) 286(10): 8308.

35. Hashimoto D, Ohmuraya M, Hirota M, Yamamoto A, Suyama K, Ida S, Okumura Y, Takahashi $\mathrm{E}$, Kido $\mathrm{H}$, Araki $\mathrm{K}$ and Baba $\mathrm{H}$ : Involvement of autophagy in trypsinogen activation within the pancreatic acinar cells in The journal of cell biology. (2008) 181(7): 1065-1072.

36. Mareninova OA, Hermann K, French SW, O'Konski MS, Pandol SJ, Webster P, Erickson AH, Katunuma N, Gorelick FS, Gukovsky I and Gukovskaya AS: Impaired autophagic flux mediates acinar cell vacuole formation and trypsinogen activation in rodent models of acute pancreatitis in The Journal of clinical investigation. (2009) 119(11): 3340-3355.

37. Jacob TG, Sreekumar VI, Roy TS and Garg PK: Electron-microscopic evidence of mitochondriae containing macroautophagy in experimental acute pancreatitis: Implications for cell death in Pancreatology. (2014) 14(6): 454-458.

38. Liu R, Qi H, Wang J, Wang Y, Cui L, Wen Y and Yin $\mathrm{C}: 2014$. Ulinastatin activates the renin-angiotensin system to ameliorate the pathophysiology of severe acute pancreatitis in Journal of gastroenterology and hepatology. (2014) 29(6): 1328-1337.

39. Manohar M, Verma AK, Venkateshaiah SU, Sanders NL and Mishra A: Pathogenic mechanisms of pancreatitis in World journal of gastrointestinal pharmacology and therapeutics. (2017) 8(1):10.

40. Jung KH, Song SU, Yi T, Jeon MS, Hong SW, Zheng HM, Lee HS, Choi MJ, Lee DH and Hong SS: Human bone marrow-derived clonal mesenchymal stem cells inhibit inflammation and reduce acute pancreatitis in rats in Gastroenterology. (2011) 140(3): 998-1008.

41. Tu XH, Song JX, Xue XJ, Guo XW, Ma YX, Chen ZY, Zou ZD and Wang L: Role of bone marrowderived mesenchymal stem cells in a rat model of severe acute pancreatitis in World Journal of Gastroenterology. (2012) 18(18): 2270.

42. Meng HB, Gong J, Zhou B, Hua J, Yao L and Song ZS: Therapeutic effect of human umbilical cordderived mesenchymal stem cells in rat severe acute pancreatitis in International journal of clinical and experimental pathology. (2013) 6(12): 2703.

43. Xiong RB, Li Q, Wan WR, Guo JQ, Luo BD and Gan L: 2014. Effects and mechanisms of vitamin $A$ and vitamin $E$ on the levels of serum leptin and other related cytokines in rats with rheumatoid arthritis in Experimental and therapeutic medicine. (2014) 8(2): 499-504.

44. El-Feki MA, Amin HM, Abdalla AA and Fesal $\mathrm{M}$ : Immunomodulatory and Anti-Oxidant Effects of Alpha-Lipoic Acid and Vitamin E on Lipopolysaccharide-induced Liver Injury in Rats in Sciences. (2016) 6(03): 460-467.

45. Hussein SA, Abdel-Aal SA and Elghwab AIM: Biochemical role of wheat germ oil on biomarkers of oxidative stress and inflammatory response in 
a rat model of endotoxemia in Benha Vet Med J. (2014) 27:157-167.

46. Khedr NF: Fish oil and wheat germ oil supplementation modulates brain injury in streptozotocin-induced diabetic rats in Journal of diabetes. (2017) 9(11): 1012-1022.

47. Dong L, Tan X, Fu M,Zhao JandGeQ:Experimental Study on Bone Marrow Mesenchymal Stem Cells for the Treatment of Acute Pancreatitis in Rats in MOJ App Bio Biomech. (2018) 2(1): 00036.

48. Lee RH, Pulin AA, Seo MJ, Kota DJ, Ylostalo J, Larson BL, Semprun-Prieto L, Delafontaine $\mathrm{P}$ and Prockop DJ: 2009. Intravenous hMSCs improve myocardial infarction in mice because cells embolized in lung are activated to secrete the anti-inflammatory protein TSG-6 in Cell stem cell. (2009) 5(1): 54-63.

49. Pittenger M: Sleuthing the source of regeneration by MSCs in Cell stem cell. (2009) 5(1): 8-10.

50. Xiong J, Ni J, Hu G, Shen J, Zhao Y, Yang L, Shen J, Yin G, Chen C, Yu G. and Hu Y: Shikonin ameliorates cerulein-induced acute pancreatitis in mice in Journal of ethnopharmacology. (2013) 145(2): 573-580.

51. Ropolo A, Grasso D, Pardo R, Sacchetti ML, Archange C, Re AL, Seux M, Nowak J, Gonzalez $\mathrm{CD}$, Iovanna JL and Vaccaro MI: The pancreatitisinduced vacuole membrane protein 1 triggers autophagy in mammalian cells in Journal of Biological Chemistry. (2007): 282(51):37124-33.

52. Hegyi P, Rakonczay Jr Z, Sári R, Góg C, Lonovics $\mathrm{J}$, Takács $\mathrm{T}$ and Czakó L: L-arginine-induced experimental pancreatitis in World journal of gastroenterology. (2004) 10(14): 2003.

53. Zhao H, He Z, Huang D, Gao J, Gong Y, Wu H, $\mathrm{Xu} \mathrm{A}$, Meng $\mathrm{X}$ and Li Z: Infusion of bone marrow Mesenchymal stem cells attenuates experimental severe acute pancreatitis in rats in Stem cells international. (2016) 2016:7174319.

54. Yang B, Bai B, Liu CX, Wang SQ, Jiang X, Zhu CL and Zhao QC: Effect of umbilical cord mesenchymal stem cells on treatment of severe acute pancreatitis in rats in Cytotherapy. (2013) 15(2): 154-162.

55. Kawakubo K, Ohnishi S, Kuwatani $M$ and Sakamoto N: Mesenchymal stem cell therapy for acute and chronic pancreatitis in Journal of gastroenterology. (2018) 53:1-5.

56. Yin, G., Hu, G., Wan, R., Yu, G., Cang, X., Xiong, J., Ni, J., Hu, Y., Xing, M., Fan, Y. and Xiao, W: 2016. Role of microvesicles from bone marrow mesenchymal stem cells in acute pancreatitis in Pancreas (2016) 45(9):1282-1293.

57. He Z, Hua J, Qian D, Gong J, Lin S, Xu C, Wei G, Meng H, Yang T, Zhou B and Song Z: Intravenous hMSCs Ameliorate Acute Pancreatitis in Mice via Secretion of Tumor Necrosis Factor- $\alpha$ Stimulated Gene/Protein 6 in Scientific reports. (2016) $6: 38438$.

58. Choi SB, Bae GS, Jo IJ, Wang S, Song HJ and Park SJ: Berberine inhibits inflammatory mediators and attenuates acute pancreatitis through deactivation of JNK signalling pathways in Molecular immunology. (2016) 74:27-38.

59. Buchwalow I, Schnekenburger J, Tiemann K, Samoilova V, Bankfalvi A, Poremba C, Schleicher C, Neumann J and Boecker W: 2013. L-arginineNO-cGMP signalling pathway in pancreatitis in Scientific reports. (2013) 3:1899.

60. Meher S, Rath S, Sharma R, Rout B, Mishra TS, Sasmal PK and Sinha MK: Pathophysiology of Oxidative Stress and Antioxidant Therapy in Acute Pancreatitis in Journal of Molecular Biomarkers and Diagnosis. (2015) 6(6):257.

61. De Oliveira GA, Cheng RY, Ridnour LA, Basudhar D, Somasundaram V, McVicar DW, Monteiro HP and Wink DA: Inducible nitric oxide synthase in the carcinogenesis of gastrointestinal cancers in Antioxidants and redox signaling. (2017) 26(18):1059-1077.

62. Fuchs P, Perez-Pinzon MA and Dave KR: Cerebral Ischemia in Diabetics and Oxidative Stress in Diabetes: Oxidative Stress and Dietary Antioxidants. (2013) pp: 15-23. Elsevier Inc.

63. Thomas DD, Heinecke JL, Ridnour LA, Cheng RY, Kesarwala AH, Switzer CH, McVicar DW, Roberts DD, Glynn S, Fukuto JM and Wink DA: Signaling and stress: the redox landscape in NOS2 biology in Free Radical Biology and Medicine. (2015) 87:204-225.

64. Yang J, Liu XX, Fan H, Tang Q, Shou ZX, Zuo DM, Zou Z, Xu M, Chen QY, Peng Y, Deng SJ, Liu YJ: Extracellular vesicles derived from bone marrow mesenchymal stem cells protect against experimental colitis via attenuating colon inflammation, oxidative stress and apoptosis in PLoS One (2015) 10(10): e0140551

65. Inan M, Bakar E, Cerkezkayabekir A, Sanal F, Ulucam E, Subaşı C and Karaöz E: Mesenchymal stem cells increase antioxidant capacity in intestinal ischemia/reperfusion damage in Journal of pediatric surgery. (2017) 52(7):1196-1206. 
66. Akool ES: Molecular mechanisms of the protective role of wheat germ oil against cyclosporin A-induced hepatotoxicity in rats in Pharmaceutical biology. (2015) 53(9): 1311-1317.
67. Kovalska I, Dronov O, Zemskov S, Deneka E and Zemskova M: Patterns of pathomorphological changes in acute necrotizing pancreatitis in International journal of inflammation. (2012) 2012:508915. 


\section{الملخص العربى}

\section{دراسة هستولوجية على تأثير الخلايا الجز عية المستخرجة من نخاع العظام

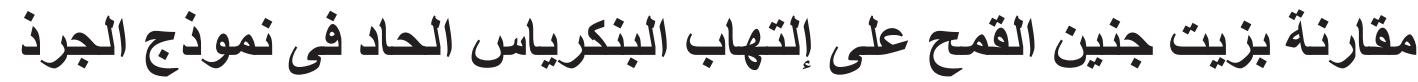 سحر عزت نصر، دينا محمد رضوان، الشيماء جمال أبوالخير ومي مصطقي حامد قسم الهستولوجيا ـ كلية الطب - جامعة القاهرة}

الخلفية والأهداف: الخلفية: إلتهاب البنكرياس الحاد (AP) هو إضطر اب إلتهابي شائع في الجهاز الهضدي. يمكن للخايا الجذعية الوسيطة (MSCs) وزيت جنين القمح (WGO) تحسين إلتهاب البنكرياس الحاد من خلال تأثير هما المضاد للإلتهاب و المضاد للأكسدة. الهدف: تقييم ومقارنة التأثير ات العلاجية المحتملة للخلايا الجذعية الوسيطة المستمدة من نخاع العظام(BMSCs) مقابل زيت جنين القمح على إلتهاب البنكرياس الحاد. طرق البحث والنتائج: تم تقسيم V ع من الفئران البيضاء الذكور البالغين إلى ؟ مجموعات. المجموعة الضابطة الأولى (العدد = r ا ). تم إحداث إلتهاب البنكرياس الحاد في الفئران الـ هب المتبقية عن طريق الحقن البريتوني (I.P)

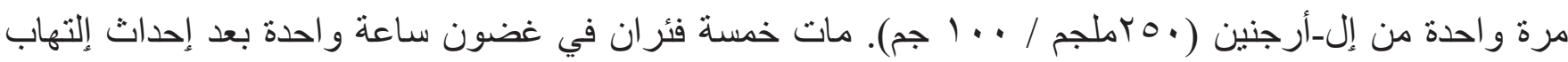
البنكرياس الحاد، تم تقسيم البقية عشو ائيا إلي المجموعة الثانية (مجموعة إلتهاب البنكرياس الحادمA ؛ العدد = • ( ) التي لم تثلق أي علاج ، المجموعة الثالثة (مجموعة BMSCs ؛ العدد = • ( ) و المجموعة الر ابعة (مجموعة WGO، العدد = · (1). بعد ساعة واحدة من إحداث AP ، تم حقن المجموعة الثالثة في الغثاء البريتوني ا مل من خلايا

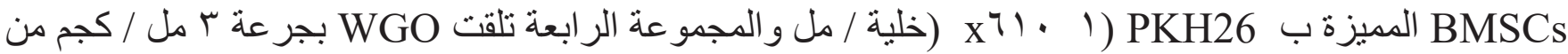
وزن الجسم عن طريق الفم كل گr ساعة لمدة r أيام متتالية. تم جمع عينات الدم بعد ع ساعة وفي اليوم الرابع بعد إحداث الـ AP للتقييم الكيميائي الحيوي لأميلاز ، والليباز ، والإنترلوكين ـ اب ، والإنترلوكين · ا في مصل الدم. بعد ذلك ، تم التضحية بالحيوانات وتم تحضير عينات من البنكرياس للصباغة بالهيماتوكسيلين والأيوسين (H\&E) و الصبغة الهستوكيميائية مناعية بإستخدام مصنّع أكسيد النيتريك المحفز (iNOS) و الأجسام المضادة للأنسولين. أجريت قياسات مورفومترية بإستخدام محلل الصورة. النتائج: أظهرت المجموعة الثانية تلف البنكرياس على نطاق و اسع مرتبط بزيادة مستويات الأميليز و الليباز و الإنترلوكين ـ ا ب في مصل الدم و إنخفاض مستوى الإنترلوكين ـ ـ تم الكثف عن زيادة ملحوظة في نسبة منطقة الصبغة المناعية لiNOS وتغير غير ملحوظ في الصبغة المناعية للأنسولين. من ناحية أخرى، أظهرت مجموعة BMSCs ومجموعة WGO تحسنا في النتائج الكيميائية الحيوية و النسيجية والمناعية مع

BMSCs نتائج أفضل في مجمو عة الخلاصة: تمنلك BMSCs فعالية علاجية أفضل في علاج AP مقارنة مع WGO 